\title{
Analisis Kinerja Pajak Daerah Tulungagung
}

\author{
Damas Dwi Anggoro ${ }^{a}$ *, Andhyka Muttaqin ${ }^{\mathrm{b}}$ \\ ${ }^{a b}$ Universitas Brawijaya, Malang, Jawa Timur, Indonesia
}

INFORMASI ARTIKEL

\section{Article history:}

Dikirim tanggal: 24 Juni 2019

Revisi pertama tanggal: 28 Juli 2019

Diterima tanggal: 28 Juli 2019

Tersedia online tanggal: 22 Agustus 2019

Keywords: local tax, local own-source revenue, growth analysis, contribution, performance, overlay analysis

\section{ABSTRACT}

Good local tax management is a strategy in optimizing local tax revenues. This can increase Local Own-source Reveneu (PAD), which is a benchmark for regional independence and can provide prosperity to the community through regional development. Analysis of local tax performance is important to determine the condition of the problems that occur at this time regarding the management of local taxes in Tulungagung district. There are four technical analyzes used, namely the analysis of growth, contribution, performance and overlay analysis which is a tool to dissect all objects of regional tax in Tulungagung district. Thus a strategy can be formulated that can provide concrete recommendations to optimize local tax revenues as one of the spearheads in increasing PAD and prosperity in Tulungagung District.

\section{INTISARI}

Pengelolaan pajak daerah yang baik menjadi strategi dalam mengoptimalkan penerimaan pajak daerah. Hal ini dapat meningkatkan Pendapatan Asli Daerah (PAD) yang menjadi tolak ukur kemandirian daerah dan dapat memberikan kemakmuran kepada masyarakat melalui pembangunan daerah. Analisis kinerja pajak daerah menjadi penting untuk mengetahui kondisi permasalahan yang terjadi saat ini perihal pengelolaan pajak daerah di kabupaten Tulungagung. Terdapat Empat teknis analisis yang digunakan yaitu analisis pertumbuhan, kontribusi, kinerja dan analisis overlay yang menjadi alat untuk membedah seluruh objek pajak daerah di kabupaten Tulungagung. Dengan demikian dapat dirumuskan strategi yang dapat memberi rekomendasi konkret guna mengoptimalkan penerimaan pajak daerah sebagai salah satu ujung tombak dalam meningkatkan PAD dan kemakmuran di Kabupaten Tulungagung.

2019 FIA UB. All rights reserved.

\section{Pendahuluan}

Otonomi daerah mengharuskan daerah untuk lebih aktif dalam mencari sumber penerimaan guna membiayai pengeluaran dan pembangunan pemerintah daerah. Kebijakan desentralisasi fiskal sebagai tindak lanjut dari kebijakan otonomi, daerah mendapat kewenangan untuk menggali sumber PAD selain dari transfer dana pemerintah pusat dalam membiayai kebutuhan daerah. Guna menggali potensi sumber-sumber keuangan, pemerintah daerah diberi peluang untuk menetapkan jenis PAD dengan memperhatikan ketentuan yang diatur dalam Undang-Undang Perimbangan Keuangan Pusat dan Daerah Tahun 2004.

Penerimaan pajak daerah menjadi ujung tombak yang digunakan untuk membiayai anggaran yang telah

* Corresponding author. Tel.: +62-813-3403-6261; e-mail: andhyka@ub.ac.id 
ditentukan, terlebih lagi melihat tingginya potensi pajak daerah dan kewenangan yang dimiliki daerah sehingga perlu memaksimalkan pengelolaan pemerintah daerah dalam rangka mendukung peningkatan PAD. Oleh karena itu, setiap daerah perlu untuk lebih concern akan hal ini, salah satunya di Kabupaten Tulungagung.

Keberadaan pajak daerah di Kabupaten Tulungagung masih memiliki potensi pendapatan yang cukup besar dan masih memungkinkan untuk memberikan kontribusi yang lebih besar terhadap PAD. Selama beberapa tahun terakhir (2013-2017) tercatat bahwa pertumbuhan pendapatan dari pajak daerah ratarata mencapai 33,97\%. Pada tahun 2017 pajak daerah di Kabupaten Tulungagung mempunyai target (APBD) sebesar Rp. 69.712.859.763,00 dan mampu terealisasi sebesar Rp. 85.826.143.046,20 atau sebesar 123,11\%.

Berdasarkan realisasi penerimaan pajak daerah yang di Kabupaten Tulungagung pada Tahun 2017, perlu dilakukan analisis yang lebih mendalam terkait dengan kondisi dan perkembangan dari pajak daerah yang dihasilkan, sehingga dapat diketahui berbagai permasalahan yang dihadapi oleh OPD maupun langkahlangkah/ upaya yang telah dilakukan, sehingga atas dasar dari hasil analisis tersebut dapat dirumuskan berbagai kebijakan yang dapat mendukung peningkatan pengelolaan pajak daerah di Kabupaten Tulungagung. Oleh sebab itu peneliti mengambil judul penelitian "Pengelolaan Pajak Daerah Guna Meningkatkan PAD (Studi Kasus pada OPD Kabupaten Tulungagung)".

\section{Teori}

\section{$2.1 \quad P A D$}

Pendapatan Asli Daerah adalah penerimaan yang diperoleh daerah dari sumber-sumber dalam wilayahnya sendiri yang dipungut berdasarkan peraturan daerah sesuai dengan peraturan perundang-undangan yang berlaku (Ahmad Yani, 2002). Sumber PAD diantaranya Pajak Daerah, Retribusi Daerah, Hasil Pengolahan Kekayaan Daerah yang Dipisahkan, Lain-lain PAD yang Sah.

\subsection{Pajak Daerah}

Mardiasmo (2009) menyebutkan bahwa pajak merupakan iuran wajib yang dilakukan oleh orang pribadi atau badan kepada daerah tanpa imbalan langsung yang seimbang yang dapat dipaksakan berdasarkan peraturan perundang-undangan yang berlaku di gunakan untuk membiayai penyelenggarakan pemerintah daerah dan pembangunan daerah.

\subsection{Asas Pemungutan Pajak}

Menurut Devas dalam Anggoro (2017), menyebutkan terdapat lima tolak ukur pajak daerah dinilai baik, yaitu: a) Hasil, cost of collection harus lebih rendah dari revenue productivity;

b) Keadilan, pemungutan pajak sebaiknya dilakukan dengan adil, tidak sewenang-wenang;

c) Efisiensi ekonomi, pungutan pajak harus tetap memperhatikan faktor perekonomian;

d) Kemampuan Melaksanakan, pajak harus dapat dilaksanakan, dari sudut kemauan politik dan tata usaha; dan

e) Kecocokan, pajak diharuskan cocok sebagai sumber penerimaan daerah.

\subsection{Tingkat Pertumbuhan}

Tingkat pertumbuhan digunakan untuk mengetahui tingkat pertumbuhan masing-masing jenis pajak daerah di Kabupaten Tulungagung.

\subsection{Tingkat Kontribusi}

Tingkat kontribusi digunukana untuk menganalisis kontribusi masing-masing jenis pajak daerah di Kabupaten Tulungagung.

\subsection{Klasifikasi Jenis Pajak Daerah (Overlay)}

Analisis overlay digunakan untuk melihat deskripsi kegiatan jenis pajak daerah potensial berdasarkan kriteria pertumbuhan dan kriteria kontribusi. Untuk mengetahui jenis pajak daerah diperlukan identifikasi atau klasifikasi kondisi yang didasarkan pada jumlah serta perkembangan setiap jenis PAD. Identifikasi ini dilakukan dengan cara mematrik antara komposisi penerimaan dan pertumbuhan penerimaan. Berdasarkan analisis overlay dan klasifikasi retribusi daerah secara garis besar dikelompokan menjadi empat kondisi:

a) Prima: Retribusi daerah memberikan kontribusi dan pertumbuhan sama dengan atau lebih dari $1 \%$;

b) Potensial: Retribusi daerah memberikan kontribusi sama dengan atau lebih dari $1 \%$ sedangkan pertumbuhan kurang dari $1 \%$;

c) Berkembang: Retribusi daerah memberikan kontribusi kurang dari $1 \%$ sedangkan pertumbuhan sama dengan atau lebih dari $1 \%$;

d) Terbelakang: Retribusi daerah memberikan kontribusi dan pertumbuhan kurang dari $1 \%$.

\subsection{Kinerja Pajak Daerah}

Analisis kinerja pajak daerah dilakukan dengan menggunakan perhitungan dan analisis tingkat ekonomis, tingkat efisiensi dan tingkat efektivitas.

\subsubsection{Tingkat Ekonomis}

Menunjukkan perbandingan antara realisasi biaya dengan anggaran biaya yang ditetapkan. Kriteria yang digunakan dalam menilai tingkat ekonomis pajak daerah adalah: 
Tabel 1 Kriteria Tingkat Ekonomis Pajak Daerah

\begin{tabular}{|c|l|l|}
\hline No & \multicolumn{1}{|c|}{$\begin{array}{c}\text { Persentase Kinerja } \\
\text { Keuangan }\end{array}$} & \multicolumn{1}{|c|}{ Kriteria } \\
\hline 1 & Kurang dari $100 \%$ & Ekonomis \\
\hline 2 & Sama dengan $100 \%$ & Berimbang \\
\hline 3 & Lebih dari $100 \%$ & Tidak Ekonomis \\
\hline
\end{tabular}

Sumber: Mahsun, 2013

\subsubsection{Efisiensi}

Menunjukkan nilai yang dihitung berdasarkan persentase biaya pemungutan pajak daerah dengan realisasi penerimaan pajak daerah.

Tabel 2 Tingkat Efisiensi Pajak Daerah

\begin{tabular}{|c|l|l|}
\hline No & \multicolumn{1}{|c|}{ \% Kinerja Keuangan } & \multicolumn{1}{|c|}{ Kriteria } \\
\hline 1 & Kurang dari 100\% & Efisien \\
\hline 2 & $100 \%$ & Berimbang \\
\hline 3 & Lebih dari $100 \%$ & Tidak Efisien \\
\hline
\end{tabular}

Sumber: Mahsun, 2013

\subsubsection{Efektivitas}

Merupakan perbandingan antara realisasi dan target penerimaan pajak daerah, sehingga dapat digunakan sebagai ukuran keberhasilan dalam melakukan pungutan.

Tabel 3 Tingkat Efektivitas Pajak Daerah

\begin{tabular}{|c|l|l|}
\hline No & \multicolumn{1}{|c|}{$\%$ Kinerja Keuangan } & \multicolumn{1}{|c|}{ Kriteria } \\
\hline 1 & $>100 \%$ & Sangat Efektif \\
\hline 2 & $100 \%$ & Efektif \\
\hline 3 & $90-99 \%$ & Cukup Efektif \\
\hline 4 & $75-89 \%$ & Kurang Efektif \\
\hline 5 & $<75 \%$ & Tidak Efektif \\
\hline
\end{tabular}

Sumber: Mahmudi, 2010

Pada kegiatan ini tingkat efektivitas juga ditinjau berdasarkan perbandingan antara realisasi retribusi daerah terhadap PAD. Kriteria yang digunakan dalam menilai efektivitas pajak daerah ini adalah sebagai berikut:

Tabel 4 Tingkat Efektivitas Pajak Daerah terhadap PAD

\begin{tabular}{|c|l|l|}
\hline No & \multicolumn{1}{|c|}{ Persentase Kinerja } & \multicolumn{1}{|c|}{ Kriteria } \\
\hline 1 & $1,72 \%$ keatas & Sangat Efektif \\
\hline 2 & $1,30-1,72 \%$ & Efektif \\
\hline 3 & $0,87-1,29 \%$ & Cukup Efektif \\
\hline 4 & $0,43-0,86 \%$ & Kurang Efektif \\
\hline 5 & Dibawah $0,43 \%$ & Tidak Efektif \\
\hline
\end{tabular}

Sumber: Mahsun, 2013

\section{Metode Penelitian}

Pendekatan penelitian yaitu kuantitatif deskriptif. Instrumen penelitian digunakan dalam pengumpulan data, analisis data bersifat kuantitatif/ statistik. Metode yang dipakai bertujuan untuk mendeskripsikan objek penelitian ataupun hasil penelitian. Objek pada penelitian ini adalah BAPENDA Kabupaten Tulungagung dan menggunakan data primer maupun sekunder, data primer didapat dari opini atau informasi yang disampaikan oleh staf atau pimpinan OPD. Data sekunder didapat dari buku, makalah, hasil penelitian, peraturan dan dokumentasi yang dilakukan oleh OPD.

Teknik pengumpulan data pada penelitian ini menggunakan kuesioner, wawancara dan studi dokumen. Teknik analisis data menggunakan empat teknik analisis, yaitu analisis pertumbuhan, kontribusi, dan analisis kinerja (tingkat ekonomis, efisiensi, dan efektivitas).

\section{Hasil Penelitian dan Pembahasan}

Guna optimalisasi penerimaan pajak daerah, pemerintah daerah harus memaksimalkan segala potensi daerahnya dengan meningkatkan kapasitas atau kemampuan yang optimal dalam memungut pajak daerah. Berikut ini disajikan analisis Pajak Daerah Kabupaten Tulungagung Tahun 2017.

\subsection{Analisis Pengelolaan Pajak Daerah \\ 4.1.1 Pajak Hotel}

Jumlah realisasi Tahun 2016 tercatat Rp. 2.980.530.053,- dan mengalami pertumbuhan negatif sebesar -1,89\% pada Tahun 2017 (Rp. 2.925.114.480,-). Penurunan disebabkan oleh penurunan penyelenggaraan even - even di Kabupaten Tulungagung, bahkan pada Tahun 2017 tidak terdapat even besar berskala nasional. Pada Tahun 2016 banyak even nasional, seperti beberapa race yang diadakan, yamaha enduro trail, kalender ISSI, dan sebagainya, sehingga tingkat hunian hotel Tahun 2016 menjadi cukup tinggi. Untuk tingkat kontribusi Pajak Hotel terhadap total penerimaan Pajak Daerah Tahun 2016 tercatat sebesar 4,4\%, sedangkan pada Tahun 2017 mengalami penurunan menjadi sebesar 3,4\%. Pemerintah Kabupaten Tulungagung berhasil mencapai target penerimaan pada Tahun $2016(111 \%)$ dari target dan Tahun 2017 (106,39\%) dengan tingkat kategori sangat efektif.

Apabila dilihat dari tingkat efektivitas yang diukur melalui perbandingan antara realisasi Pajak Hotel terhadap PAD di Kabupaten Tulungagung pada Tahun 2016 dan 2017 tercatat sebesar 0,87\% dan 0,58\%, artinya dalam pemungutan Pajak Hotel pemerintah Kabupaten Tulungagung masuk dalam kriteria kurang efektif.

\subsubsection{Pajak Restoran}

Pada Tahun 2016 jumlah realisasi Pajak Restoran di Kabupaten Tulungagung tercatat sebanyak Rp. 5.956.754.832,- dan mengalami pertumbuhan sebesar $18,3 \%$ pada Tahun 2017, sehingga menjadi sebanyak Rp. 7.342.798.238,-. Peningkatan tersebut disebabkan salah satunya oleh bertambahnya jumlah restoran di Kabupaten Tulungagung dengan berbagai jenisnya. Sedangkan tingkat kontribusi Pajak Restoran terhadap total penerimaan Pajak Daerah pada Tahun 2016 
adalah sebesar 8,8\%, sedangkan pada Tahun 2017 mengalami penurunan menjadi sebesar $8,5 \%$, mengingat terdapat pertumbuhan pada jenis pajak lainnya dengan nilai yang lebih besar.

Efektivitas penerimaan pajak restoran Tahun 2016 (209,11\%) dan Tahun 2017 (133,81\%) masuk dalam kriteria sangat efektif. Tingkat efektivitas Pajak Restoran terhadap PAD di Kabupaten Tulungagung pada Tahun 2016 dan Tahun 2017 masuk dalam kriteria sangat efektif dan efektif.

\subsubsection{Pajak Hiburan}

Realisasi Pajak Hiburan di Kabupaten Tulungagung pada Tahun 2016 tercatat sebanyak Rp. 930.824.930,00,. Jumlah tersebut mengalami pertumbuhan sebesar 23,27\% pada Tahun 2017, sehingga menjadi Rp. 7.342.798.238,-. Peningkatan tersebut diakibatkan salah satunya karena bertambahnya jumlah objek hiburan di Kabupaten Tulungagung, baik yang hiburan yang telah disediakan dalam suatu tempat secara permanen maupun yang bersifat insidentil. Sedangkan kontribusi Pajak Hiburan terhadap total realisasi pajak daerah Tahun 2016 tercatat sebesar 1,37\%, sedangkan pada Tahun 2017 mengalami peningkatan menjadi sebesar $1,64 \%$.

Pemerintah Kabupaten Tulungagung telah berhasil memenuhi target penerimaan Pajak Hiburan pada Tahun 2016 (126,52\%) dan 2017 (160,32\%) masuk dalam kriteria sangat efektif.

Tingkat efektivitas yang diperoleh dari perbandingan antara realisasi Pajak Hiburan terhadap PAD di Kabupaten Tulungagung Tahun 2016 (0,27\%) dan $2017(0,28 \%)$ termasuk dalam kriteria tidak efektif.

\subsubsection{Pajak Reklame}

Pada Tahun 2016 jumlah realisasi Pajak Reklame tercatat sebanyak Rp. 973.791.846,-, dimana realisasi tersebut mengalami pertumbuhan negatif sebesar $-9,64 \%$ pada Tahun 2017 atau menjadi sebanyak Rp. 910.451.069,-. Penurunan tersebut disebabkan salah satunya karena pada Tahun 2016 terdapat pemasangan reklame insidentil yang signifikan sebagai akibat dari adanya even besar yang berskala nasional, sedangkan pada Tahun 2017 di Kabupaten Tulungagung tidak terdapat even besar berskala nasional, dan mayoritas tempat reklame dipakai untuk kegiatan non komersial seperti pengenalan bakal calon bupati dan wakil bupati. Kontribusi pajak reklame terhadap realisasi pajak daerah Tahun 2016 tercatat sebesar $1,44 \%$, dan terjadi penurunan pada Tahun 2017 menjadi sebesar 1,06\%. Terjadinya penurunan kontribusi sebesar $0,38 \%$ antara lain disebabkan oleh adanya penurunan realisasi pada jenis pajak tersebut.

Pemerintah Kabupaten Tulungagung pada Tahun 2016 belum berhasil memenuhi target penerimaan Pajak Reklame, dimana target penerimaan tercatat sebanyak
Rp. 1.366.763.580,-, sedangkan realisasi penerimaannya sebanyak Rp. 973.791.846,-. Dengan demikian tingkat efektivitas Tahun 2016 sebesar 71,25\% dengan kriteria tidak efektif. Pada Tahun 2017 target penerimaan Pajak Reklame di Kabupaten Tulungagung tercatat sebanyak Rp. 900.000.000,- dengan realisasi penerimaan sebanyak Rp. 910.451.069,-, artinya pemerintah Kabupaten Tulungagung pada Tahun 2017 telah berhasil mencapai target penerimaan dengan tingkat efektivitas sebesar $101,16 \%$ atau memiliki kriteria sangat efektif. Apabila dilihat dari tingkat efektivitas perbandingan realisasi Pajak Reklame terhadap PAD di Kabupaten Tulungagung tergolong kriteria tidak efektif Tahun 2016 (0,28\%) dan Tahun 2017 (0,18\%).

\subsubsection{Pajak Penerangan Jalan (PPJ)}

Pada Tahun 2016 jumlah realisasi Pajak Penerangan Jalan di Kabupaten Tulungagung tercatat mengalami pertumbuhan sebesar 26,64\%. Peningkatan realisasi Pajak Penerangan Jalan di Kabupaten Tulungagung disebabkan salah satunya oleh pertumbuhan perumahanperumahan baru di Kabupaten Tulungagung yang disertai dengan permintaan fasilitas listrik, selain itu adanya kenaikan konsumsi listrik pada masing-masing rumah yang sudah tersedia aliran listrik juga turut menyebabkan kenaikan pendapatan dari jenis pajak tersebut. Pajak Penerangan Jalan berkontribusi 33,9\% Tahun 2016 dan 33,7\% Tahun 2017 terhadap total penerimaan pajak daerah.

Apabila dilihat dari tingkat efektivitas pencapaian Pajak Penerangan Jalan pada Tahun 2016 sebesar 102,13\% dan Tahun 2017 sebesar 127,07\% dengan kategori sangat efektif. Tingkat efektivitas sebesar 6,68\% pada Tahun 2016 dan 5,76\% untuk Tahun 2017, yang berarti masuk dalam kriteria sangat efektif.

\subsubsection{Pajak Mineral Bukan Logam dan Batuan}

Realisasi penerimaan Tahun 2016 tercatat Rp.347.215.033,- dan mengalami pertumbuhan sebesar 3,91\% pada Tahun 2017 menjadi Rp. 360.775.706,-. Peningkatan diakibatkan adanya pertumbuhan perumahan baru di Kabupaten Tulungagung yang disertai dengan permintaan material bangunan, sehingga dengan potensi mineral bukan logam dan batuan yang tersedia akan meningkatkan produksi dalam rangka memenuhi permintaan masyarakat yang semakin banyak. Tingkat kontribusi terhadap total penerimaan Pajak Daerah Tahun 2016 tercatat sebesar $0,51 \%$, dan mengalami penurunan menjadi sebesar $0,42 \%$ pada Tahun 2017, mengingat pertumbuhan yang dihasilkan pada Tahun 2017 sangat kecil.

Jika dilihat dari tingkat efektifitas penerimaan pada Tahun 2016 (118,7\%) dan Tahun 2017 (114,98\%); maka Pemerintah Kabupaten Tulungagung dalam hal tingkat efektivitas termasuk dalam kategori sangat efektif. 
Apabila dilihat dari tingkat efektivitas terhadap PAD pada Tahun 2016 tercatat sebesar $0,10 \%$ dan sebesar 0,07 pada Tahun 2017 artinya masuk dalam kriteria tidak efektif.

\subsubsection{Pajak Parkir}

Pada Tahun 2016 jumlah realisasi Pajak Parkir di Kabupaten Tulungagung tercatat sebanyak Rp. 102.444.398,- dan mengalami pertumbuhan sebesar $110,70 \%$ pada Tahun 2017, sehingga menjadi sebanyak Rp. 215.852.850,-. Terjadinya peningkatan disebabkan oleh adanya penertiban tempat parkir diluar bahu jalan yang menjadi objek Pajak Parkir. Tingkat kontribusi Pajak Parkir terhadap total penerimaan Pajak Daerah Kabupaten Tulungagung pada Tahun 2016 tercatat sebesar 0,15\%, sedangkan pada Tahun 2017 mengalami peningkatan menjadi sebesar $0,25 \%$. Pada Tahun 2016 dan 2017 tingkat efektivitas pajak parkir 118,70\% dan $214,78 \%$, sehingga tergolong dalam kriteria sangat efektif.

Apabila dlihat dari tingkat efektivitas yang diperoleh dari perbandingan antara realisasi pajak parkir terhadap PAD di Kabupaten Tulungagung pada Tahun 2016 dan Tahun 2017 tercatat sebesar $0,03 \%$ dan $0,04 \%$, sehingga tergolong dalam kategori tidak efektif.

\subsubsection{Pajak Air Tanah}

Jumlah realisasi Pajak Air Tanah di Kabupaten Tulungagung Tahun 2016 diketahui sebesar Rp. 303.525.520,- dan mengalami pertumbuhan sebesar $1,88 \%$ pada Tahun 2017, sehingga menjadi Rp. 309.235.064,-. Terjadinya peningkatan realisasi oleh adanya ekstensifikasi pajak air tanah di Kabupaten Tulungagung melalui peningkatan jumlah wajib pajak yang dilakukan pemungutan. Tingkat kontribusi pajak air tanah terhadap total penerimaan pajak daerah pada Tahun 2016 tercatat sebesar $0,44 \%$, dan mengalami penurunan menjadi sebesar $0,36 \%$ pada Tahun 2017 yang dipengaruhi oleh rendahnya tingkat pertumbuhan pada tahun yang sama.

Apabila dilihat dari tingkat efektivitas pencapaian pajak air tanah pada Tahun 2016 sebesar 120,99\% dan sebesar 112,92\% pada Tahun 2017 dengan kriteria sangat efektif. Tingkat efektivitas terhadap PAD pada Tahun 2016 mencapai sebesar 0,09\% dan 0,06 pada Tahun 2017, artinya dalam pemungutan pajak air tanah dengan memperhitungkan ketercapaian terhadap PAD termasuk dalam kriteria tidak efektif.

\subsubsection{Pajak Sarang Burung Walet}

Jumlah realisasi pajak sarang burung walet tercatat sebanyak Rp. 7.450.000,- pada Tahun 2016 dan mengalami pertumbuhan negatif pada Tahun 2017 sebesar $-5,37 \%$, sehingga menjadi Rp. 7.050.000,-. Terjadinya penurunan tersebut antara lain disebabkan oleh minimnya objek pajak sarang burung walet, sulitnya mencari pengelola/ wajib pajak, serta tidak adanya pasar yang menampung hasil penjualan sarang burung walet di Kabupaten Tulungagung. Sedangkan tingkat kontribusi terhadap total penerimaan Pajak Daerah pada Tahun 2016 tercatat sebesar $0,011 \%$, sedangkan pada Tahun 2017 mengalami penurunan menjadi sebesar $0,008 \%$.

Tingkat efektivitas pada Tahun 2016 dan Tahun 2017 sebesar $106,42 \%$ dan $107,71 \%$ masuk dalam kriteria sangat efektif. Apabila dilihat dari tingkat efektivitas pajak sarang burung walet terhadap PAD di Kabupaten Tulungagung pada Tahun 2016 tercatat sebesar 0,002\% dan Tahun 2017 sebesar 0,001\% yang artinya masuk dalam kriteria tidak efektif dari segi pemungutan.

\subsubsection{Pajak Bumi dan Bangunan Perdesaan Perkotaan (PBB-P2)}

Jumlah realisasi PBB-P2 di Kabupaten Tulungagung Tahun 2016 tercatat sebanyak Rp. 25.493.683.398,- dan tumbuh sebesar $6,13 \%$ pada Tahun 2017, sehingga menjadi sebesar Rp. 27.056.181.455,-. Terjadinya peningkatan disebabkan adanya upaya intensifikasi maupun ekstensifikasi, antara lain melalui peningkatan pendataan obyek dan subjek PBB-P2 dengan pendaftaran, penilaian, dan penentuan klasifikasi obyek pajak. Untuk tingkat kontribusi PBB-P2 terhadap total penerimaan Pajak Daerah pada Tahun 2016 tercatat sebesar 37,7\%, namun pada Tahun 2017 kontribusi tersebut mengalami penurunan menjadi sebesar $31,5 \%$. Tingkat efektivitas berturut-turut sebesar $104,06 \%$ dan $103,27 \%$ masuk kriteria sangat efektif. Begitu juga dengan tingkat efektivitas terhadap PAD masuk dalam kategori sangat efektif (7,44\% dan 5,38\%).

\subsubsection{Bea Perolehan Hak Atas Tanah dan Bangunan (BPHTB)}

Jumlah realisasi BPHTB di Kabupaten Tulungagung sebesar Rp. 7.484.812.632,- pada Tahun 2016 dan tumbuh sebesar 117,98\% menjadi Rp. 16.315.152.091,-. Terjadinya peningkatan tersebut salah satunya disebabkan oleh adanya pertumbuhan bangunan perumahan dan aktivitas jual beli real estate turut mendorong terjadinya peningkatan. Tingkat kontribusi realisasi BPHTB terhadap total penerimaan pajak daerah pada Tahun 2016 tercatat sebesar 11,09\%, sedangkan pada Tahun 2017 dengan adanya pertumbuhan yang signifikan menyebabkan terjadinya peningkatan kontribusi menjadi sebesar $19,00 \%$.

Tingkat efektivitas pada Tahun 2016 dan Tahun 2017 sebesar 103,32\% dan 163,15\% masuk dalam kriteria sangat efektif. Begitu juga terhadap PAD masuk dalam kriteria sangat efektif $(2,18 \%$ dan $3,24 \%)$. 
Analisis Tingkat Ekonomis dan Efisiensi Pajak Daerah

Tingkat ekonomis menunjukkan besarnya perbandingan antara realisasi biaya dengan anggaran biaya yang ditetapkan. Berdasarkan data sekunder menunjukkan bahwa nilai tingkat ekonomis pajak daerah Pemerintah Kabupaten Tulungagung tercatat sebesar 97,93\% dengan kriteria ekonomis, artinya sebesar 97,93\% biaya yang telah dianggarkan untuk menunjang pengelolaan dan peningkatan Pajak Daerah selama Tahun 2017 telah terealisasi melalui berbagai kegiatan yang dilaksanakan oleh Badan Pendapatan Daerah Kabupaten Tulungagung.

Tingkat efisiensi ditunjukkan dari nilai yang dihitung berdasarkan persentase biaya pemungutan dengan penerimaan. Efisiensi Pajak Daerah secara keseluruhan di Kabupaten Tulungagung tercatat sebesar 5,04\% dan masih menunjukan kriteria efisien. Kondisi tersebut menggambarkan bahwa besarnya biaya yang dikeluarkan untuk menunjang pengelolaan dan peningkatan Pajak Daerah selama Tahun 2017 dibandingkan dengan keseluruhan jumlah pajak daerah yang berhasil dihimpun masih sangat kecil, sehingga dalam pengelolaannya termasuk efisien.

\subsection{Analisis Overlay Pajak Daerah}

Analisis overlay pajak daerah digunakan untuk mendeskripsikan objek-objek pajak yang potensial berdasarkan kriteria pertumbuhan dan kontribusi. Analisis ini dilakukan dengan membuat matriks antara komposisi penerimaan dan pertumbuhan penerimaan. Secara lebih lengkap dapat dilihat pada tabel berikut:

Tabel 5 Tingkat Pertumbuhan dan Kontribusi Pajak Daerah Kabupaten Tulungagung 2017

\begin{tabular}{|c|l|r|r|c|}
\hline No & $\begin{array}{l}\text { Jenis Pajak } \\
\text { Daerah }\end{array}$ & $\begin{array}{c}\text { Tingkat } \\
\text { Petumbuhan (\%) }\end{array}$ & $\begin{array}{c}\text { Kontribusi terhadap } \\
\text { Total Pajak (\%) }\end{array}$ & $\begin{array}{c}\text { Analisis } \\
\text { Overlay }\end{array}$ \\
\hline 1 & Pajak Hotel & $-1,89$ & 3,4 & Potensial \\
\hline 2 & $\begin{array}{l}\text { Pajak } \\
\text { Restoran }\end{array}$ & 23,27 & 8,5 & Prima \\
\hline 3 & $\begin{array}{l}\text { Pajak } \\
\text { Hiburan }\end{array}$ & 23,27 & 1,64 & Prima \\
\hline 4 & $\begin{array}{l}\text { Pajak } \\
\text { Reklame }\end{array}$ & $-9,64$ & 1,06 & Potensial \\
\hline 5 & PPJ & 26,64 & 33,7 & Prima \\
\hline 6 & $\begin{array}{l}\text { Pajak } \\
\text { Mineral } \\
\text { Bukan } \\
\text { Logam dan } \\
\text { Batuan }\end{array}$ & 3,91 & 0,42 & Berkembang \\
\hline 7 & $\begin{array}{l}\text { Pajak } \\
\text { Parkir }\end{array}$ & 110,7 & & Prima \\
\hline 8 & $\begin{array}{l}\text { Pajak Air } \\
\text { Tanah }\end{array}$ & 1,88 & 0,25 & Berkembang \\
\hline 9 & $\begin{array}{l}\text { Pajak } \\
\text { Sarang } \\
\text { Burung } \\
\text { Walet }\end{array}$ & $-5,37$ & 0,36 & Berkembang \\
\hline 10 & PBB-P2 & & 0,008 & Terbelakang \\
\hline 11 & BPHTB & 6,13 & & Prima \\
\hline
\end{tabular}

Sumber: Hasil , 2019
Berdasarkan pada analisis overlay diatas dapat diketahui bahwa pajak restoran, pajak hiburan, pajak penerangan jalan, PBB-P2 dan BPHTB masuk dalam kategori prima, artinya pajak daerah memberikan kontribusi dan pertumbuhan sama dengan atau lebih dari $1 \%$. Lebih lanjut, pajak hotel dan pajak reklame masuk dalam kategori potensial dimana kontribusi pajak daerah sama dengan atau lebih dari $1 \%$ sedangkan pertumbuhannya kurang dari $1 \%$. Adapun pada pajak mineral bukan logam dan batuan, pajak parkir dan pajak air tanah masuk kategori berkembang, dimana pajak daerah memberikan kontribusi kurang dari $1 \%$ sedangkan pertumbuhan sama dengan atau lebih dari $1 \%$. Sedangkan pajak sarang burung walet masuk kategori terbelakang dengan kontribusi dan pertumbuhan kurang dari $1 \%$.

\section{Kesimpulan}

Tingkat efektivitas Pajak Daerah di Kabupaten Tulungagung pada Tahun 2017 menunjukkan bahwa pajak parkir menduduki posisi pertama dengan capaian 214,78\%; posisi kedua adalah BPHTB dengan nilai efektivitas sebesar $163,15 \%$; posisi ketiga pajak hiburan dengan nilai efektivitas sebesar $160,32 \%$. Jenis pajak daerah yang memiliki nilai efektivitas terendah adalah pajak sarang burung walet, yaitu sebesar 100,71\%.

Penilaian tingkat efektivitas juga dilihat berdasarkan kontribusi yang diberikan terhadap PAD yang merupakan jenis pendapatan pemerintah daerah secara mandiri. Terdapat tiga objek pajak yang memiliki tingkat efektivitas tertinggi (sangat efektif) dari 11 objek pajak daerah yang dikelola di Kabupaten Tulungagung, yaitu pajak penerangan jalan dengan tingkat efektivitas sebesar 5,76\%, PBB-P2 dengan tingkat efektivitas sebesar $5,38 \%$, serta BPHTB dengan tingkat efektivitas sebesar $3,24 \%$ dan pajak sarang burung walet memiliki nilai efektivitas terendah sebesar $0,001 \%$.

Kabupaten Tulungagung memiliki nilai tingkat ekonomis sebesar 97,93\% dengan kriteria ekonomis pada Tahun 2017. Sedangkan tingkat efisiensinya menunjukan kriteria efisien dengan nilai sebesar 5,04\%.

Berdasarkan analisis overlay, pajak restoran, pajak hiburan, pajak penerangan jalan, PBB-P2 dan BPHTB masuk katagori prima dimana memberikan kontribusi dan pertumbuhan sama dengan atau lebih dari $1 \%$. Kemudian untuk pajak hotel dan pajak reklame dikatagorikan potensial dimana memberikan kontribusi sama dengan atau lebih dari $1 \%$ sedangkan pertumbuhannya kurang dari $1 \%$. Selain itu Pajak mineral bukan logam dan batuan, pajak parkir dan pajak air tanah masuk kategori berkembang, dimana memberikan kontribusi kurang dari $1 \%$ sedangkan pertumbuhan sama dengan atau lebih dari $1 \%$. Untuk kategori terbelakang ditempati oleh pajak sarang burung walet dengan kontribusi dan pertumbuhannya kurang dari $1 \%$. 
Saran yang direkomendasikan diantaranya, memperbaiki sistem penetapan target pajak daerah, perbaikan pengelolaan alokasi biaya pajak daerah, perlunya peningkatan koordinasi antar OPD, sinkronisasi berbagai sistem elektronik terkait dengan pemungutan pajak daerah, sehingga mampu menunjang pengelolaan yang efektivitas meningkatkan intensifikasi dan ekstensifikasi pajak daerah untuk mengoptimalkan penerimaan dalam jangka pendek, serta meninjau ulang tarif, objek pajak dengan mempertimbangkan perkembangan perekonomian saat ini khususnya pajak sarang burung walet.

\section{Daftar Pustaka}

Agus, Prawoto. (2011). Pengantar Keuangan Publik. Yogyakarta: BPFE.

Anggoro, Damas Dwi. (2017). Pajak Daerah dan Retribusi Daerah. Malang: UB Press.

Mahmudi. (2010). Manajemen Kinerja Sektor Publik. Yogyakarta: UPP STIM YKPN.

Mahsun, Mohamad. (2013). Pengukuran Kinerja Sektor Publik. Yogyakarta: BPFE.

Mardiasmo. (2009). Akuntansi Sektor Publik. Yogyakarta: Andi.

Undang-Undang Nomor 33 Tahun 2004 tentang Perimbangan Keuangan Pusat dan Daerah.

Yani, Ahmad. (2002). Hubungan Keuangan Antara Pemerintah Pusat dan Daerah di Indonesia. Jakarta: Raja Grafindo Persada. 